\title{
Growth and Nutritional Responses of Cowpea (cv. Soronko) to Short-term Elevated Temperature
}

\author{
Thalukanyo Nevhulaudzi \\ Department of Environmental Sciences, University of South Africa, South \\ Africa
}

\begin{abstract}
Khayalethu Ntushelo
Department of Agriculture and Animal Health, University of South Africa, South Africa
\end{abstract}

\begin{abstract}
Sheku Alfred Kanu
Department of Agriculture and Animal Health, University of South Africa, South Africa; and Department of Crop Science, Njala University, Njala, Sierra Leone
\end{abstract}

Additional index words. biomass, crude protein, flowering, plant biomass, preflowering, postflowering

\begin{abstract}
Short-term variations in temperature associated with climate change have been noted to affect the physiological processes and metabolite profile of plants, including the nutritional status, ultimately affecting their growth and development. An evaluation of the effects of elevated temperatures on the growth and nutritional quality of cowpea was performed during this experiment. The main objective was to evaluate the effects of short-term elevated temperatures on the nutritional quality of cowpea at different growth stages. Surface-sterilized seeds of cowpea (cv. Soronko) were germinated in pots in the glasshouse. At different growth stages (preflowering, flowering, and postflowering), plants were incubated in growth chambers set at three different temperature regimes $\left(25,30\right.$, and $\left.35^{\circ} \mathrm{C}\right)$ for a period of 7 days. Compared with control $\left(25^{\circ} \mathrm{C}\right)$, exposure to both elevated temperatures $\left(30\right.$ and $\left.35^{\circ} \mathrm{C}\right)$ reduced the whole plant fresh weight and dry weight by $30 \%$ and $52 \%$ and $42 \%$ and $29 \%$, respectively, at the preflowering stage, and by 31 and $60 \%$ and 47 and $63 \%$, respectively, at the flowering/ anthesis stage. However, no significant difference in whole plant biomass was noted between elevated temperatures $(35 \%)$ and the control temperature at the postflowering stage. Short-term exposure to an elevated temperature $\left(35^{\circ} \mathrm{C}\right)$ increased the shoot crude protein content $(5.59 \mathrm{~N} \%)$ of cowpea compared with control $(3.77 \mathrm{~N} \%)$ and preflowering stage. In contrast, at the flowering stage, an elevated temperature $\left(35^{\circ} \mathrm{C}\right)$ reduced the crude protein content $(1.77 \%)$ of the shoot compared with control $(5.59 \%)$. At an elevated temperature $\left(35^{\circ} \mathrm{C}\right)$, the preflowering and flowering stages of cowpea were most affected compared with control. These results suggest that the preflowering and flowering stages of cowpea compared with the postflowering stage are more susceptible to elevated temperatures $\left(30\right.$ to $\left.35^{\circ} \mathrm{C}\right)$.
\end{abstract}

Cowpea (Vigna unguiculata L. Walp) is an important nutritious legume cultivated in most regions in Africa, including Western and Southern Africa. In sub-Saharan Africa, rural farmers cultivate cowpeas for subsis-

\footnotetext{
Received for publication 14 May 2020. Accepted for publication 30 June 2020.

Published online 6 August 2020.

We acknowledge the University of South Africa and National Research Foundation (NFR) for funding this project. A special thank you is extended to Mustapha Mohhamed $(\mathrm{PhD}$ candidate, Nitrogen Fixation Laboratory, Tshwane University of Technology, Pretoria, RSA) for providing cowpea (cv. Soronko) seeds used in this project.

S.A.K. is the corresponding author. E-mail: kanu. popfred@gmail.com/kanusa@njala.edu.sl.

This is an open access article distributed under the CC BY-NC-ND license (https://creativecommons. org/licenses/by-nc-nd/4.0/).
}

tence, income, and nutrients, but also, to a lesser extent, as feed for livestock (Kritzinger, 2004). The crop is largely used for other purposes in other countries in Central and West Africa (Singh et al., 2002). For example, in West Africa, the leaves are eaten as vegetables. The seeds can be cooked and eaten with stew as a meal. When the young green leaves of cowpea are eaten as a vegetable, it can provide protein contents ranging between 27.1 and $34.7 \%$ to humans and animals (Ahenkora et al., 1998; Jasper and Norman, 1983). Mature seeds contain (per edible portion, $100 \mathrm{~g}$ ) the following: 56 to $66 \mathrm{~g}$ carbohydrates; 22 to $24 \mathrm{~g}$ protein; $11 \mathrm{~g}$ water; 5.9 to $7.3 \mathrm{~g}$ crude fiber; 3.4 to $3.9 \mathrm{~g}$ ash; 1.3 to $1.5 \mathrm{~g}$ fat; and minerals such $\mathrm{P}, \mathrm{Ca}$, and $\mathrm{Fe}(0.146 \mathrm{~g}, 0.104-0.076 \mathrm{~g}$, and $0.005 \mathrm{~g}$, respectively) (Asante et al., 2006; Belane, 2011). The edible grain of cowpea is sug- gested to contain protein contents ranging from $22 \%$ to $25 \%$ and carbohydrates and ash contents of $56.8 \%$ and $3.6 \%$, respectively (Belane et al., 2011; Gonçalves et al., 2016). Research of the nutritional value of the cowpea leaves and immature pods has indicated that the leaf has nutritional value similar to that of black nightshade and sweetpotatoes leaves, whereas the green pods have fewer antinutritional factors than the dried seeds (Gonçalves et al., 2016). The nutritional benefits associated with the grain and leaves of cowpea are well-documented; therefore, the crop is an inexpensive source of nutrients for rural communities in subSaharan Africa. This legume crop has the advantage of growing in poor-nutrient soils in marginal areas in the country because of its ability to perform symbiotic nitrogen $(\mathrm{N})$ fixation with microorganisms (rhizobacteria) (Belane, 2011; Belane et al., 2011). In addition, the crop is tolerant to heat and drought associated with climate change in marginal areas; therefore, it can be considered a climate-smart crop (Awika and Duodu, 2017).

Globally, changes in climate can alter rainfall patterns, evaporation, runoff, and soil moisture storage in most regions, including areas under agricultural cultivation, thus affecting the growth and development of crops. It has been reported that the occurrence of insufficient moisture during flowering, pollination, and grain-filling is harmful to most crops (Eitzinger et al., 2010). In addition, increases in average temperatures or shortterm temperature increases causing hightemperature stress on plants are associated with climate change. Changes in temperature are noted to affect the physiological processes and metabolite profile of plants, including the nutritional status, ultimately affecting their growth and development. Studies have reported the sensitivity of the different growth stages of plants, including legumes, to climatic conditions (Hatfield and Prueger, 2015; Hatfield et al., 2008; Prasad et al., 2002). Agricultural systems in the tropics are expected to be impacted by drastic short-term changes in temperature, frost (Barlow et al., 2015), and soil moisture. In particular, African agricultural production may be affected significantly by the increase in global warming associated with climate change (Watson et al., 1997). In developing sub-Saharan countries such as South Africa, the majority of cowpea cultivation is located in places that are already too hot or dry, and poor farmers in rural areas are less able to adapt (Mendelsohn et al., 1994). In subSaharan Africa, cowpea has received more research attention, leading to breeding for earliness, high grain yield, and pest and disease resistance (Singh and Ntare, 1985). However, there is a need for rural farmers to cultivate cowpea genotypes that are tolerant to future elevated temperatures. In addition, scarce literature shows the effects of elevated temperatures on the crop's nutrition, especially at different growth stages. Therefore, the main objective of the experiment was to 
evaluate the effects of short-term elevated temperatures on the nutritional quality of cowpea at different growth stages.

\section{Materials and Methods}

\section{Plant materials}

Seeds of three cowpea genotypes (Asetanapa, Soronko, and Nyira) were obtained from the Crop Research Institute in Kumasi, Ghana. Among these three cowpea genotypes, the Soronko genotype (cv. Soronko) was noted to have the highest germination percentage and longest plumule length at an elevated temperature $\left(35^{\circ} \mathrm{C}\right)$ in a previous study (Nevhulaudzi, 2019); therefore, it was selected for this experiment. Seeds of the Soronko genotype were germinated in pots filled with acid wash sand.

\section{Plant growth media and experimental conditions}

Acid-washed sand was obtained from Masstores (Pty) Ltd., Johannesburg, South Africa. The acid sand was thoroughly washed using tap water to remove nutrients. One-liter planting pots (14-inch) were used for the experiment. Cowpea seeds were surfacedsterilized as described previously (PuleMeulenberg et al., 2010). The surfacedsterilized cowpea (cv. Soronko) seeds (three) were germinated in pots containing acidwashed sand, and the emergent seedlings were thinned to one per pot. The seedlings were grown in a glasshouse set at a day/night temperature regime of $25 / 18{ }^{\circ} \mathrm{C}$ with a supplementary light intensity of $300 \mu \mathrm{mol} \cdot \mathrm{m}^{-2} \cdot \mathrm{s}^{-1}$; an overhead irrigation system was used with each plant receiving $63 \mathrm{~mL}$ of water per day split into three regimes of $5 \mathrm{~min}$ each. The experiment was conducted at the University of South Africa (Unisa) Florida campus, Gauteng Province (lat. $26^{\circ} 10^{\prime} 30^{\prime \prime} \mathrm{S}$, long. $\left.27^{\circ} 55^{\prime} 22.8^{\prime \prime} \mathrm{E}\right)$.

\section{Fertilization of cowpea}

Seedlings of cowpea in pots were grown with modified 1/4-strength $\mathrm{N}$-free solution as a source of nutrients (Broughton and Dilworth, 1970). Stock solutions of the $\mathrm{N}$-free nutrient were prepared as described by Broughton and Dilworth (1970), and details of salts used are shown in Table 1.

For each $10 \mathrm{~L}$ of full-strength stock solution, $5.0 \mathrm{~mL}$ of each solution was taken and added to $5 \mathrm{~L}$ of water and then diluted to $10 \mathrm{~L}$;
$1 \mathrm{~N} \mathrm{NaOH}$ was used to adjust the $\mathrm{pH}$ to 6.6 to 6.8 (Broughton and Dilworth, 1970). The seedlings were irrigated with the $\mathrm{N}$-free nutrients solutions twice during the $7 \mathrm{~d}$ in growth chambers (Nüve test cabinet TK 120; China).

Commercial inoculants for cowpea were obtained from Stimuplants CC in Pretoria, South Africa. Specifically, a packet of the powdered inoculant with Bradyrhizobium spp. CB756 strains was used to inoculate cowpea seedlings. Approximately $2 \mathrm{~g}$ of the powder inoculant was mixed with $500 \mathrm{~mL}$ of distilled water; using a sticker, it was applied as a slurry to cowpea seeds before planting. Two weeks after seedling establishment, the same mixture of inoculant was applied close to the root zone of seedlings to ensure inoculation of each plant.

\section{Experimental treatments: Biomass determination and nutrient analysis}

Cowpea growth and nutritional responses to elevated temperature. For this experiment, three seedlings of cowpea (cv. Soronko) were exposed to three temperature regimes [25 (control), 30, and $35^{\circ} \mathrm{C}$ ] as treatments for a 7-d period. For each of these treatments, three seedlings of similar phenology were randomly selected from seedlings grown in the glasshouse at three different growth and developmental stages [preflowering, $40 \mathrm{~d}$ after planting (DAP); flowering, $90 \mathrm{DAP}$; and postflowering, 123 DAP). Using a complete randomized block design, the plants were incubated in three separate growth chambers set at the different temperatures for a 1-week period. In each growth chamber, the humidity was set and maintained at $70 \%$, and the lights were on (0000-1200 HR) and off (1201-2359 HR) for $12 \mathrm{~h}$ for $7 \mathrm{~d}$. Seedlings were irrigated with tap water every $24 \mathrm{~h}$ for $7 \mathrm{~d}$ and fertilized with modified 1/4-strength $\mathrm{N}$-free solution twice during the 7-d incubation. The three different stages of plant development (preflowering, flowering, and postflowering) exposed to the different temperature regimes were assessed after $7 \mathrm{~d}$ of incubation for the effects of temperature on the growth and nutritional quality of cowpea. Throughout the experiment, there were no incidences of plant diseases and pests, and plants were healthy before and during the 7-d incubation period.

Plant biomass. For each treatment, the plant biomass was determined after $7 \mathrm{~d}$ of incubation. A weighing balance was used to determine the fresh weights immediately after washing with tap water. For dry weight determination, the plant parts were ovendried at $60{ }^{\circ} \mathrm{C}$ for $72 \mathrm{~h}$ to a constant weight, and the weight was measured using a weighing balance. The plant biomass [fresh weight (FW) and dry weight (DW)] was determined for each growth stage exposed to the treatments.

\section{Determination of nitrogen (crude protein) and carbon}

Sample preparation. For this experiment, finely ground oven-dried shoots of plants exposed to the three different temperature regimes (treatments) were used. Sample grinding was performed using a mechanical mill (Knifetec 1095 Sample Mill) and passed through an 80-mesh sieve to obtain uniformed particles. Samples were uniformed powder finely ground and homogenized for repeatable and consistent results. Typically, samples should be ground to a fineness of $<0.5 \mathrm{~mm}$. Approximately 0.1 to $0.5 \mathrm{~g}$ of the sample was weighed for each sample analysis.

Sample analysis. Determination of $\mathrm{N} /$ crude protein and carbon (C) in samples was performed using a LECO Trumac CN analyzer (832 series; St. Joseph, MI). Approximately $0.3 \mathrm{~g}$ of the plant sample was weighed in a crucible transferred to a suitable position in the autoloader. These steps were repeated for each sample to be analyzed. Before each sample analysis, preweighed homogeneous samples were placed in a large ceramic boat and loaded in the purge chamber located in the front of the horizontal ceramic high-temperature furnace. After the entrained atmospheric gas was purged from the sample, the ceramic boat was introduced into the furnace regulated at a temperature of 1100 to $1450{ }^{\circ} \mathrm{C}$. Complete oxidation of the macro sample was ensured by a pure oxygen environment within the furnace, with additional oxygen being directed onto the sample via the ceramic lance. The ceramic boat and all ash from the sample were removed from the furnace at the end of combustion, leaving the furnace free of ash build-up. For each treatment applied to the three different growth stages, three replicate shoot samples were analyzed for the concentration of its crude protein $/ \mathrm{N}$ and $\mathrm{C}$ contents.

Table 1. Nitrogen-free plant nutrients and their concentrations in stock solutions.

\begin{tabular}{|c|c|c|c|c|}
\hline Stock solutions & Form & Source/element & Mass/liter $(\mathrm{g} / \mathrm{L})$ & Concn \\
\hline \multirow[t]{3}{*}{$\mathrm{C}$} & Fe-citrate & $\mathrm{Fe}$ & 607 & $20.0 \mathrm{~mm}$ \\
\hline & $\mathrm{MgSO}_{4} \cdot 7 \mathrm{H}_{2} \mathrm{O}$ & $\mathrm{Mg}$ & 123.3 & $0.5 \mathrm{M}$ \\
\hline & $\mathrm{MnSO}_{4} \cdot 2 \mathrm{H}_{2} \mathrm{O}$ & $\mathrm{Mn}$ & 0.338 & $2.0 \mathrm{~mm}$ \\
\hline \multirow[t]{3}{*}{ D } & $\mathrm{H}_{3} \mathrm{BO}_{3}$ & B & 0.247 & $4.0 \mathrm{~mm}$ \\
\hline & $\mathrm{ZnSO}_{4} \cdot 7 \mathrm{H}_{2} \mathrm{O}$ & $\mathrm{Zn}$ & 0.288 & $1.0 \mathrm{~mm}$ \\
\hline & $\mathrm{NaMoO}_{2} \cdot 2 \mathrm{H}_{2} \mathrm{O}$ & Mo & 0.048 & $0.2 \mathrm{~mm}$ \\
\hline
\end{tabular}




\section{Data analysis}

Data regarding growth parameters [plant biomass (FW and DW)] and nutritional contents of cowpea shoot were analyzed using a one-way analysis of variance. All parameters and concentration measurements were tested at a significance level of $P<0.05$, and the Duncan multiple range test was used for separation between treatment means. Statistica version 10 (StatSoft Inc., Tulsa, OK) was used for all statistical analyses.

\section{Results and Discussion}

Cowpea growth response to short-term elevated temperatures. In this experiment, short-term (7-d exposure) elevated temperatures significantly $(P<0.05)$ affected all three growth stages of cowpea (cv. Soronko) incubated in growth chambers. For each cowpea growth stage exposed to $7 \mathrm{~d}$ of elevated temperatures $\left(30\right.$ to $\left.35^{\circ} \mathrm{C}\right)$, the plant biomass decreased significantly compared with control $\left(25{ }^{\circ} \mathrm{C}\right)$. For example, at 40 DAP (preflowering stage), in comparison with control, the whole plant fresh weight and dry weight of cowpea exposed to an elevated temperature $\left(35^{\circ} \mathrm{C}\right)$ were reduced by 42 and $29 \%$, respectively, and at $30{ }^{\circ} \mathrm{C}$, cowpea whole plant fresh weight and dry weight were reduced by 30 and $52 \%$, respectively (Table 2). At 90 DAP (flowering/anthesis stage), in comparison with control, cowpea's plant fresh weight and dry weight exposed to an elevated temperature $\left(35^{\circ} \mathrm{C}\right)$ were reduced by $47 \%$ and $63 \%$, respectively; at $30{ }^{\circ} \mathrm{C}$, the fresh weight and dry weight were reduced by $31 \%$ and $60 \%$, respectively (Table 2). Similarly, at 123 DAP (postflowering stage), the growth response of cowpea was affected by a higher temperature $\left(30^{\circ} \mathrm{C}\right)$ compared with control. Cowpea's fresh weight and dry weight were reduced by $31 \%$ and $60 \%$, respectively, when exposed to a high temperature $\left(30^{\circ} \mathrm{C}\right)$ compared with control; however, no significant difference in plant biomass was noted between elevated temperatures $\left(30\right.$ to $\left.35^{\circ} \mathrm{C}\right)$ and control (Table 2).

As several authors have reported, the plant growth rate throughout the life cycle is affected by temperature extremes (Hatfield and Prueger, 2015; Hatfield et al., 2008; Kondache et al., 2018; Prasad et al., 2002), and the range differs among species (Lafta and Lorenzen, 1995). Across all plant species, the reproductive growth stage is more sensitive to temperature extremes, and pollination is one of the most susceptible phenological stages (Hatfield and Prueger, 2015). In general, in the plant's life cycle, anthesis, and early grain-filling stages are more sensitive to heat shock events for most crops (Barlow et al., 2015; Stone and Nicolas, 1994). In this experiment, the preflowering and flowering stages of cowpea (cv. Soronko) were more affected by temperature extremes compared with postflowering. At 90 DAP (flowering/anthesis), plants exposed to an elevated temperature $\left(35^{\circ} \mathrm{C}\right)$ showed the highest reduction in plant biomass $(47 \%$ and $63 \%$ in FW and DW, respectively) compared with those exposed to the same temperature at other growth stages $(42 \%$ and $29 \%$ at preflowering and $1 \%$ and $0 \%$ at postflowering). A recent study showed that heat stress impacts the reproductive stage and flower bud initiation, decreases the number and size of flowers, and deforms floral organs, resulting in the loss of flowers and young pods, thereby reducing the seed yield (Sita et al., 2017). Similar to this finding, the vegetative and reproductive growth stages of maize development were most affected by exposure to elevated temperatures (30 to $35^{\circ} \mathrm{C}$ ); in particular, because of decreased pollen viability (Hatfield et al., 2008), the grain yield was reduced by $80 \%$ to $90 \%$ compared with control (Hatfield and Prueger, 2015). In another related study, high temperatures $\left(31 / 29{ }^{\circ} \mathrm{C}\right.$ day/night $)$ in growth chambers significantly reduced the plant biomass of two potato genotypes (total dry weights reduced by $44 \%$ and $72 \%$ in cv. Norchip and cv. Up-to-date, respectively), and the tuber growth was more affected compared with shoot growth (Lafta and Lorenzen, 1995). Similarly, the growth stages of wheat plant were affected differently when exposed to heat shocks over short periods. Grain number reduction was highest when heat shock was applied $2 \mathrm{~d}$ before anthesis, but it was lower by two levels when applied $2 \mathrm{~d}$ after anthesis. The grain number was reduced significantly by $12 \%$ to $22 \%$ in five individual genotypes

of wheat when exposed to heat shock 10 to $30 \mathrm{~d}$ after anthesis compared with no significant reduction in the remaining 75 genotypes tested (Stone and Nicolas, 1994). In the current study, the insignificant change in plant biomass at postflowering when the control was compared with those exposed to $35{ }^{\circ} \mathrm{C}$ (Table 2 ) would suggest that the plant has the capacity to acclimatize to short-term heat events (Barlow et al., 2015). Heat stress tolerance mechanisms in plants have been linked to the production of heat shock proteins; in wheat plants, heat shock was associated with the reduction of grain yield and translocation of photosynthates to grains as well as starch synthesis (Acevedo et al., 2002; Barlow et al., 2015).

Effects of short-term elevated temperatures on cowpea crude protein and carbon content. Similarly, short-term elevated (30 to $35{ }^{\circ} \mathrm{C}$ ) temperatures significantly $(P<0.05)$ affected the nutritional quality of cowpea at different growth stages. The crude protein content $(\% \mathrm{~N})$ in the shoot of cowpea (cv. Soronko) was significantly affected compared with control at both the preflowering and flowering stages after a 7-d incubation in growth chambers (Fig. 1).

At 40 DAP (preflowering), the shoot crude protein content $(5.59 \mathrm{~N} \%)$ of cowpea (cv. Soronko) with short-term exposure to an elevated temperature $\left(35^{\circ} \mathrm{C}\right)$ was increased significantly compared with control $(3.77 \mathrm{~N}$ $\%)$. In contrast, at the flowering stage (90

Table 2. Effects of temperature on the plant biomass (g/plant) at different growth stages of cowpea (cv. Soronko) grown in a growth chamber. ${ }^{2}$

\begin{tabular}{|c|c|c|c|c|c|c|}
\hline \multirow[b]{3}{*}{ Temp $\left({ }^{\circ} \mathrm{C}\right)$} & \multicolumn{6}{|c|}{ Whole plant biomass (g/plant) } \\
\hline & \multicolumn{2}{|c|}{ Preflowering (40 DAP) } & \multicolumn{2}{|c|}{ Flowering (90 DAP) } & \multicolumn{2}{|c|}{ Postflowering (123 DAP) } \\
\hline & FW & DW & FW & DW & FW & DW \\
\hline 35 & $5.6 \pm 0.8 \mathrm{~b}$ & $3.2 \pm 0.5 b$ & $47.3 \pm 9.3 \mathrm{c}$ & $6.3 \pm 1.4 \mathrm{~b}$ & $92.6 \pm 8.8 b$ & $18.6 \pm 4.8 \mathrm{a}$ \\
\hline 30 & $6.7 \pm 1.2 \mathrm{~b}$ & $2.3 \pm 0.9 \mathrm{~b}$ & $62.0 \pm 1.3 \mathrm{~b}$ & $7.0 \pm 2.9 b$ & $81.3 \pm 8.8 b$ & $14.6 \pm 14.6 b$ \\
\hline 25 & $9.6 \pm 2.4 \mathrm{a}$ & $4.8 \pm 1.6 \mathrm{a}$ & $89.6 \pm 8.6 \mathrm{a}$ & $17.3 \pm 4.3 \mathrm{a}$ & $93.6 \pm 9.8 \mathrm{a}$ & $18.3 \pm 6.3 \mathrm{a}$ \\
\hline
\end{tabular}

F-statistic

$\begin{array}{lllllll}\text { Temp } & 3.625 * & 3.725^{*} & 5.123 * & 5.524 * & 3.270 * & 3.209 *\end{array}$

${ }^{\mathrm{z}}$ Values (mean $\pm \mathrm{SE} ; \mathrm{n}=3$ ) followed by similar letters in a column are not significantly different at $P \leq 0.05$.

$\mathrm{DAP}=$ days after planting; DW = dry weight; $\mathrm{FW}=$ fresh weight.

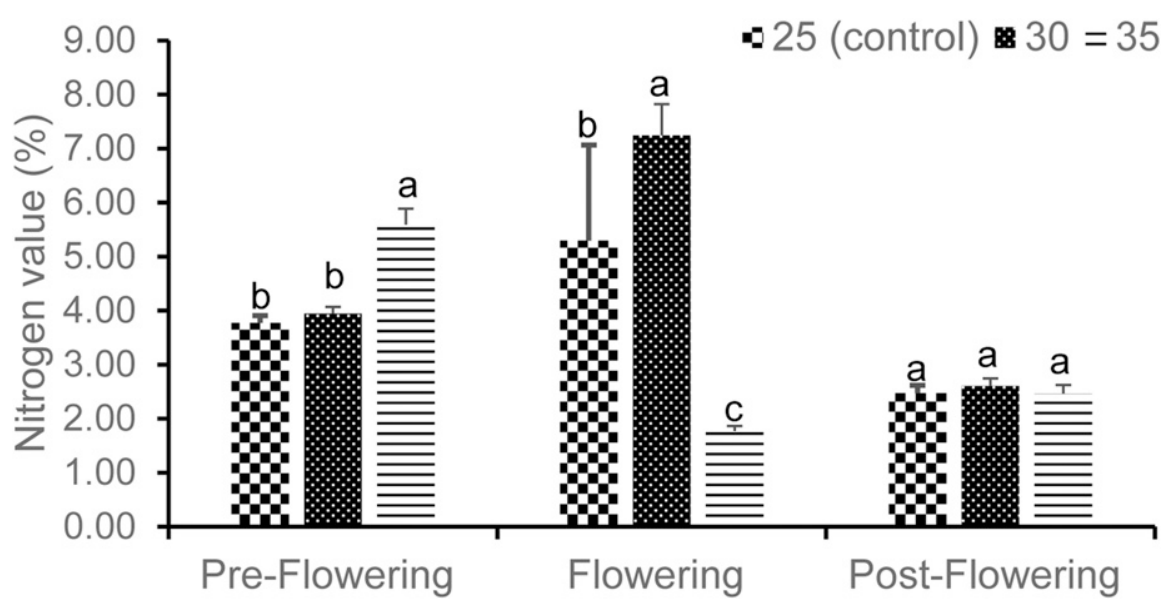

Fig. 1. Effects of short-term elevated $\left(>30^{\circ} \mathrm{C}\right)$ temperatures on the nutritional content [nitrogen value $(\% \mathrm{~N})]$ of cowpea (cv. Soronko) shoots at different growth stages. 
DAP), an elevated temperature $\left(35^{\circ} \mathrm{C}\right)$ significantly reduced the crude protein content of the shoot $(1.77 \%)$ compared with control (5.59\%). Interestingly, at $30{ }^{\circ} \mathrm{C}$, the $\mathrm{N}$ level (N\%) was significantly higher in the shoots compared with those of the control plants during the flowering stage. However, at postflowering (123 DAP), elevated temperatures $\left(30\right.$ and $\left.35{ }^{\circ} \mathrm{C}\right)$ compared with control had no significant effect on the crude protein content in shoots of cowpea (cv. Soronko) plants (Fig. 1). This finding further showed the sensitivity to elevated temperatures of the flowering stage in cowpea plants' growth and development. During the flowering stage, the crude protein content in shoots was drastically increased at $30{ }^{\circ} \mathrm{C}$ and reduced at $35^{\circ} \mathrm{C}$ compared with control. In agreement with this finding, short-term/abrupt heat stress reduced the total protein content, nutrient uptake levels, and assimilation proteins in roots of tomato plants compared with control (Giri et al., 2017), especially at the flowering stage.

Similarly, the $\mathrm{C}$ contents in shoots of cowpea (cv. Soronko) at both the preflowering and flowering stages were affected by the short-term elevated temperature compared with control. At the preflowering stage, the C content (16.7\%) in the shoots of cowpea (cv. Soronko) was increased significantly at $30{ }^{\circ} \mathrm{C}$ compared with control (15\%); however, at both the flowering and postflowering stages, no significant changes in shoot $\mathrm{C}$ contents were noted, but there was a slight decrease and increase at the flowering stage and postflowering stage, respectively, compared with control (Fig. 2).

Comparisons of the $\mathrm{C} / \mathrm{N}$ ratios in shoots of cowpea (cv. Soronko) showed that short-term elevated temperatures similarly affected the accumulation of nutrients during the different growth stages. For example, at the preflowering growth stage, the elevated temperature $\left(35^{\circ} \mathrm{C}\right)$ slightly reduced the $\mathrm{C} / \mathrm{N}$ ratio compared with control; at the flowering stage, the $\mathrm{C} / \mathrm{N}$ ratio $(22.1 \%)$ was significantly increased at $35^{\circ} \mathrm{C}$ compared with control $(11.8 \%)$. The $\mathrm{C} / \mathrm{N}$ ratio in shoots of cowpea (cv. Soronko) exposed to short-term elevated temperatures showed significant differences only at the flowering growth stage (Fig. 3). During both the preflowering and postflowering stages, there were no significant changes in the $\mathrm{C} / \mathrm{N}$ ratio in shoots of cowpea (cv. Soronko) incubated at elevated temperatures compared with control. The nutritional contents ratio results further demonstrated the susceptibility of the flowering stage to elevated temperatures in the tested crop.

In this experiment, the susceptibility of the flowering stage (90 DAP) to short-term elevated temperatures (Figs. 1-3) noted in the changes in cowpea's (cv. Soronko) shoot crude protein and $\mathrm{C}$ content was demonstrated, and this has implications for the crop's nutritional quality and yield. At anthesis, the plant's pollination process can be impacted by elevated temperatures, which can result in changes in the number of grains (Barlow et al., 2015). Heat shock is reported to impact mostly grain yield during anthesis

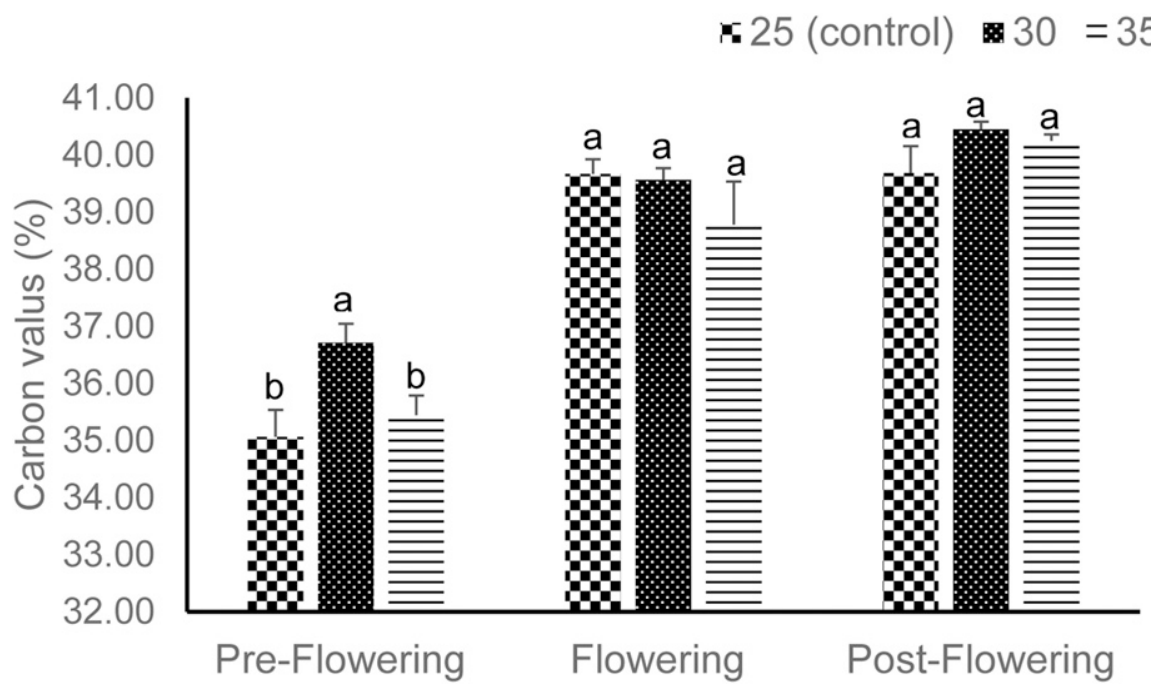

Fig. 2. Effects of short-term elevated temperatures on the nutritional content [carbon value $(\% \mathrm{C})$ ] of cowpea (cv. Soronko) shoots at different growth stages.

$$
\mathbf{2 5} \text { (control) } 30=35
$$

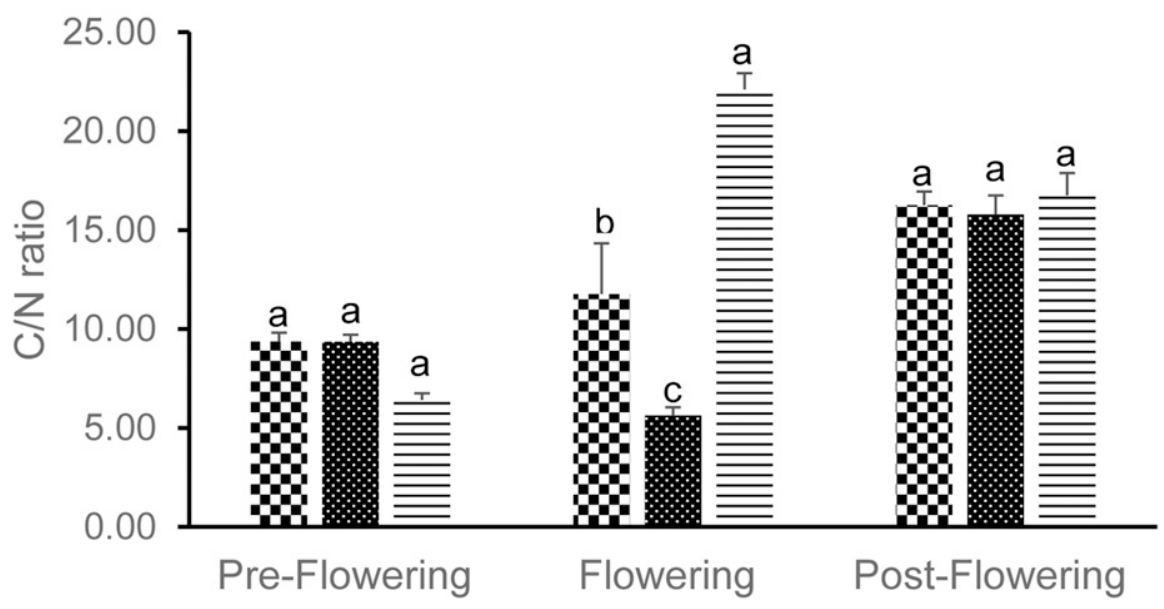

Fig. 3. Effects of short-term elevated temperatures on the nutritional content [carbon/nitrogen $(\mathrm{C} / \mathrm{N})$ ratio] of cowpea (cv. Soronko) shoots at different growth stages.

to early grain-filling in wheat crop (Barlow et al., 2015).

Although nutrients in cowpea shoots were determined in this experiment, notably, elevated temperatures have been reported to negatively affect the nutrient sink-source relationship between the root and shoot (Huang et al., 2012), which implies that decreases in root nutrients will reduce nutrient transfers to shoot. If the growth and mass of the root are affected by elevated temperatures, as reported by many authors (Heckathorn et al., 2014; Huang et al., 2012; Rennenberg et al., 2006; Wahid et al., 2007), the growth of aboveground parts (shoot) will also be affected because the supply of water and nutrients will be affected (Giri et al., 2017; Hao et al., 2012).

\section{Conclusions}

In this experiment, exposure to short-term (7 d) elevated temperatures (30 to $35{ }^{\circ} \mathrm{C}$ ) significantly affected the growth and nutritional quality of cowpea at the preflowering (40 DAP) and flowering growth stages (90 DAP). Compared with other growth stages, the plant biomass and nutrient contents of cowpea (cv. Soronko) at the flowering stage (125 DAP) were most affected by elevated temperatures. Rural farmers cultivating cowpea should adopt cropping management strategies for the protection of the flowering stage in the crop's growth cycle, especially during periods of changes in climatic conditions (temperature extremes over short periods) under climate change scenarios.

\section{Literature Cited}

Acevedo, E., P. Silva, and H. Silva. 2002. Wheat growth and physiology. Series (FAO) 0259 2525, no. 30. In: B. Curtis, S. Rajaram, and H. Gomez-Macpherson (eds.). Bread wheat. Food and Agriculture Organization of the United Nations, Rome. 
Ahenkora, K., H.K. Adu-Dapaah, and A. Agyemang. 1998. Selected nutritional components and sensory attributes of cowpea (Vigna unguiculata L. Walp) leaves. Plant Foods Hum. Nutr. 52(3):221-229.

Asante, I.K., H. Adu-Dapaah, and P. Addison. 2006. Variation in contents of crude protein and mineral elements in 32 cowpea (Vigna unguiculata (L.) Walp) accessions in Ghana. Ghana J. Agr. Sci. 39(1):83-86.

Awika, J.M. and K.G. Duodu. 2017. Bioactive polyphenols and peptides in cowpea (Vigna unguiculata) and their health promoting properties: A review. J. Funct. Foods 38:686-697.

Barlow, K.M., B.P. Christy, G.J.G. O’Leary, P.A. Riffkin, and J.G. Nuttall. 2015. Simulating the impact of extreme heat and frost events on wheat crop production: A review. Field Crops Res. 171:109-119.

Belane, A.K. 2011. Evaluating cowpea genotypes for enhanced N2 fixation and photosynthetic activity, increased grain yield, and density of dietarily-important mineral elements. $\mathrm{PhD}$ Thesis, Tshwane Univ. of Tech., Pretoria, RSA.

Belane, A.K., J. Asiwe, and F.D. Dakora. 2011. Assessment of $\mathrm{N}_{2}$ fixation in 32 cowpea (Vigna unguiculata L. Walp) genotypes grown in the field at Taung in South Africa, using $15 \mathrm{~N}$ natural abundance. Afr. J. Biotechnol. 10(55): 11450-11458.

Broughton, W.J. and M.J. Dilworth. 1970. Control of leghaemoglobin synthesis in Snake beans. Biochem. J. 125:1075-1080.

Eitzinger, J., S. Orlandini, R. Stefanski, and R.E.L. Naylor. 2010. Climate change and agriculture: Introductory editorial. J. Agr. Sci. 148:499-500.

Giri, A., S. Heckathorn, S. Mishra, and C. Krause. 2017. Heat stress decreases levels of nutrientuptake and - assimilation proteins in tomato roots. Plants 6:1-15.

Gonçalves, A., P. Goufo, A. Barros, R. DomínguezPerles, H. Trindade, E.A.S. Rosa, L. Ferreira, and M. Rodrigues. 2016. Cowpea (Vigna unguiculata L. Walp), a renewed multipurpose crop for a more sustainable agri-food system: Nutritional advantages and constraints. J. Sci. Food Agr. 96:29412951.
Hao, H.P., C.D. Jiang, S.R. Zhang, Y.D. Tang, and L. Shi. 2012. Enhanced thermal-tolerance of photosystem II by elevating root zone temperature in Prunus mira Koehne seedlings. Plant Soil 353:367-378.

Hatfield, J.L. and J.H. Prueger. 2015. Temperature extremes: Effect on plant growth and development. Weather Clim. Extrem. 10:4-10.

Hatfield, J.L., K.J. Boote, P. Fay, L. Hahn, R.C. Izaurralde, B.A. Kimball, T. Mader, J. Morgan, D. Ort, W. Polley, A. Thomson, and D. Wolfe. 2008. Agriculture, p. 9-10. In: The effects of climate change on agriculture, land resources, water resources, and biodiversity in the United States.

Heckathorn, S.A., A. Giri, S. Mishra, and D. Bista. 2014. Heat stress and roots, p. 109-136. In: N. Tuteja and S. Gill (eds.). Climate change and plant abiotic stress tolerance. Wiley Blackwell, Weinheim, Germany.

Huang, B., S. Rachmilevitch, and J. Xu. 2012. Root carbon and protein metabolism associated with heat tolerance. J. Expt. Bot. 63:3455-3465.

Jasper, K.I. and N.P. Norman. 1983. Nutrient contents of raw and cooked cowpea leaves. J. Food Sci. 48:1252-1254.

Kondache, K., D. Koffi, J.A. Kayode, S.O. Awokola, and A. Adebola. 2018. Impact of climate variability on crop yields in Southern Togo. Agricultural development and sustainable environment. Nigeria.

Kritzinger, Q. 2004. Antimicrobial activity and fumonisins associated with cowpea (Vigna unguiculata). PhD Thesis, Univ. of Pretoria, Pretoria, RSA.

Lafta, A.M. and J.H. Lorenzen. 1995. Effect of high temperature on plant growth and carbohydrate metabolism in potato. J. Plant Physiol. 109:637-643.

Mendelsohn, R., W. Nordhaus, and D. Shaw. 1994. Measuring the impact of global warming on agriculture. Amer. Econ. Rev. 84:753-771.

Nevhulaudzi, T. 2019. Interactive effects of Bacillus subtilis and elevated temperature on germination, growth and grain quality of cowpea irrigated with acid mine drainage. MSc. Dissertation, Univ. of South Africa, Pretoria, RSA.
Prasad, P.V.V., K.J. Boote, L.H.J.R. Allen, and J.M.G. Thomas. 2002. Effects of elevated temperature and carbon dioxide on seed-set and yield of kidney bean (Phaseolus vulgaris L.). Glob. Change Biol. 8:710-721.

Pule-Meulenberg, F., A.K. Belane, T. KrasovaWade, and F.D. Dakora. 2010. Symbiotic functioning and bradyrhizobial biodiversity of cowpea (Vigna unguiculata L. Walp) in Africa. BMC Microbiol. 10:89.

Rennenberg, H., F. Loreto, A. Polle, F. Brilli, S. Fares, R. Beniwal, and A. Gessler. 2006. Physiological responses of forest trees to heat and drought. Plant Biol. 06(8):556-571.

Singh, B.B. and B. Ntare. 1985. Development of improved cowpea varieties in Africa, p. 106115. In: S.R. Singh and K.O. Rachie (eds.). Cowpea research, production and utilization. Wiley, New York.

Singh, B.B., J.D. Ehlers, B. Sharma, and F.R. Freire Filho. 2002. Recent progress in cowpea breeding, p. 22-40. In: C.A. Fatokun, S.A. Tarawali, B.B. Singh, P.M. Kormawa, and M. Tamò (eds.). Challenges and opportunities for enhancing sustainable cowpea production. Proc. World Cowpea Conference III, IITA, Ibadan, Nigeria.

Sita, K., A. Sehgal, B. HanumanthaRao, R.M. Nair, P.V. Vara Prasad, S. Kumar, P.M. Gaur, M. Farooq, K.H.M. Siddique, R.K. Varshney, and H. Nayyar. 2017. Food legumes and rising temperatures: Effects, adaptive functional mechanisms specific to reproductive growth stage and strategies to improve heat tolerance. Front. Plant Sci. 8(1658):1-30.

Stone, P. and M. Nicolas. 1994. Wheat cultivars vary widely in their responses of grain yield and quality to short periods of post-anthesis heat stress. Funct. Plant Biol. 21:887-900.

Wahid, A., S. Gelani, M. Ashraf, and M. Foolad. 2007. Heat tolerance in plants: An overview. Environ. Expt. Bot. 61:199-223.

Watson, R.T., M.C. Zinyoera, and R.H. Moss. 1997. The regional impacts of climate change: An assessment of vulnerability. A special report of the IPCC Working Group II. Cambridge University Press, Cambridge. 